\title{
Included to be Excluded? A Critical Assessment on the Inclusion of Slum and Shanty Dwellers into the Urban Regeneration Project
}

\author{
Anjali Korala \\ Senior Lecturer (Grade II), Department of Political Science and Public Policy, \\ University of Colombo, Sri Lanka
}

\begin{abstract}
Sustainable Development has become a popular concept in recent development discourse. With the sustainable development goals adopted in 2015, all countries have taken actions to fulfill the goals by its target deadline. Among the goals, goal no. 11 "[m]ake cities and human settlements inclusive, safe, resilient, and sustainable" has become one of the most important sustainable development goals as cities are proponents of a country's development. Due to the highly diverse nature of urban populations, inclusion has become an important concept under this goal. Nevertheless, there are many examples around the world which suggest that vulnerable groups like slum and shanty dwellers have been excluded from the decision-making process on the development of cities.

In such a context, this article asks, to what extent were the slum and shanty dwellers in the city of Colombo included in the decision-making process of the development projects related to building a sustainable city? It uses as a case study, the Urban Regeneration Project, initiated by the Urban Development Authority (UDA) and aimed at upgrading the living conditions of slum and shanty dwellers by relocating them into modern houses. The article is based on secondary data gathered through journal articles, books, websites etc. It argues that the slum and shanty dwellers were excluded from the entire decision-making process, and that the government's decision to exclude these communities was justified based on its positivist stance when making policy decisions.
\end{abstract}

\section{KEYWORDS:}

Inclusion, relocation, Urban Regeneration Project, sustainability, development, city, Colombo, slum

Suggested Citation: Korala A. (2021). Included to be Excluded? A Critical Assessment on the Inclusion of Slum and Shanty Dwellers into the Urban Regeneration Project. University of Colombo Review (New Series III), 2(2), $133-150$.

(C) 2021 The Authors. This work is licenced under a Creative Commons Attribution 4.0 International Licence which permits unrestricted use, distribution, and reproduction in any medium, provided the original work is properly cited. 


\section{Introduction}

The city, one of the focal points in modern development discourse, is a growing organism. Over centuries, the city has evolved in terms of size, form, structure, and composition, and has been important in local and regional development (UNHabitat, 2020). The nature of the city has also changed, or been re-conceptualized and re-articulated, by town planners and policy makers over the time. Over a century ago, Maunier noted the use of different (1) morphological characteristics such as population and the presence of a fortification around the city; (2) demographical characteristics such as low birth-rate or high marriage-rate; (3) judicial definitions such as the right of the municipality or the right to trade; or sometimes the (4) functional characteristics such as some special activities, notably certain industrial activities, by historians to define a city (1910, pp. 536-539). In current development discourse, these same characteristics are now viewed under different concepts and have produced various conceptualizations on cities, mainly categorized under the "smart city" concept. Based on concepts promoted by stake holders and interest groups, these smart cities are sub-categorized in terms of "future cities", "eco city", "intelligent cities", "sustainable cities", "compact cities", "liveable cities", "digital cities", "innovative cities", "green cities" etc. (Eremia et al., 2017, p. 15). Among these categories, sustainable cities are now more popular than others due to the worldwide commitment they received through the adoption of the sustainable development goals in 2015.

With the pledge made by world leaders towards the UN's sustainable development goals (SDGs), sustainability was incorporated into the policy formulation processes of every State. With 17 goals and 169 targets, the SDGs cover the three main pillars of sustainability - the environment, economy, and society. They specifically focus on people, the planet, prosperity, peace, and partnerships as sections to be incorporated in the agenda for sustainable development (United Nations, 2015). Within this agenda, goal no. 11 - "[m] ake cities and human settlements inclusive, safe, resilient, and sustainable" - specifically focuses on rapidly growing cities and urbanization all around the world and the role they play in attaining sustainable development.

According to the United Nations, "since 2007 more than half of the world's population has been living in cities and that share is projected to rise to 60 per cent by 2030 " (United Nations, n.d.). This postulation places the city at a crucial juncture in sustainable development due to its role as a hub which connects the three pillars of the environment, the economy, and society. Globally, rapid urbanization has caused many issues in cities. Urban sprawl, the urbanization of poverty, higher unemployment, higher costs in cities, lack of adequate housing investment, housing affordability, shortage of infrastructure investment, weak financial capacity, poor urban governance, urban inequality and gender inequality, crime and human insecurity, and environmental impacts are some of these issues (Zhang, 2015 , pp. 11-22). While their relevance to urbanization is quite evident globally and often cited as a threat in achieving sustainability, authors like Jianguo Wu claim that the key to regional and global sustainability is urbanization. Wu points out that cities "epitomize the creativity, imagination, and mighty power of humanity" (2010, p. 2), and argues that they have taken up only 3 per cent of the earth's land surface but have been home to more 
than half of the world's population. He stresses, therefore, that urbanization should not be considered as the only problem, but as a part of the solution. What Wu tries to convey is that, as a human creation, cities can adapt and develop, and that a well-planned policy intervention can be helpful in resolving the challenges, finally leading to a sustainable city.

Nevertheless, creating inclusive, safe, resilient, and sustainable cities is a challenging and complex task. A city consists of numerous stakeholders and attending to the demands of each one of them is challenging. Therefore, in this process, inclusion becomes important. Granting equal opportunities for all stakeholders to voice their concerns and influence planning and implementation, which would eventually affect their lifestyles and livelihoods, should not be undervalued. Nevertheless, various examples from around the world suggest otherwise. Simon (2016) points to a double paradox when creating sustainable cities. On the one hand, making cities in high-income countries more sustainable might seem an easy task but in reality, changing resource-incentive, high-consumption economic processes and lifestyles requires enormous support, finance, and political will. On the other hand, when it comes to the cities of poor countries, the ultimate challenge or the "wicked urban problem" in turning the cities into more sustainable ones is marked by hundreds of associated problems such as the widespread poverty, resource and service deficits, and chronic traffic congestion (2016, p. 3). Thus, Simon's double paradox highlights the fact that creating sustainable cities is a challenge for both developed and developing countries in their own ways. While the lack of financial support is a challenge to the developing countries in creating sustainable cities, economic processes, and high lifestyles associated with the high-income can be a challenge to the developed countries in making their cities sustainable. Nevertheless, the problems faced by developing countries in this task can be more severe than the problems faced by developed countries as the cities in poor countries are, in most cases, run by various power blocks and networks which intentionally exclude or disenfranchise some vulnerable communities from the decision-making process.

Moreover, the city is a spatial organization and a product of an inherently political process (Williams, 1975), and managing its spatial distribution is a crucial part of creating a sustainable city. It might include freeing the land to maximize its utility, re-zoning the city, relocating various businesses and communities into various zones etc. Nevertheless, in developing countries like Sri Lanka, the manipulation of the spatial structure of the city by various governing agents (local, national, or international) in order to achieve various ends has become a common scenario. These manipulations have made the urban inhabitants increasingly disenfranchised in the decision-making process regarding the management of urban space (Purcell, 2002). The legal right to the land of some communities such as slum and shanty dwellers has to be fought for and negotiated with government officials towards a favorable outcome for such communities.

In such a context, it is worthwhile investigating to what extent the slum and shanty dwellers in the city of Colombo were included in the planning and implementation of the development projects related to building a sustainable city, and how and why the lack of space provided for their inclusion poses a challenge to achieving the sustainability of the capital city of Colombo. This problem is explored using, as a case study, the Urban Regeneration Project (URP), which relocated slum and shanty dwellers in Colombo on a 
large scale to "modern houses"1 as a strategy of improving their living standards. Initiated after the war victory in 2009, the URP was a part of fulfilling the election mandate by the then President Mahinda Rajapaksa. In 2010, as the Presidential candidate, Mahinda Rajapaksa pledged to make the city of Colombo free from shanty dwellers by 2020 (Perera et al., 2014). Under the purview of the Urban Development Authority (UDA), the URP planned to relocate nearly 70,000 to 135,000 families (between 280,000 and 500,000 people) into "modern" high-rises (Perera et al., 2014, pp. 8-9). This project was criticized over the use of military backed evictions, such as at Mews Street in Colombo's Slave Island, and for forced eviction and involuntary relocation (Perera et al., 2014; Perera, 2015). According to a survey carried out by the Center for Policy Alternatives (CPA) in 2016, only 26 per cent of the respondents stated that they were fully informed prior to the relocation process about moving, terms and conditions, the nature of the new housing, and location etc., while 35.4 per cent were somewhat informed, and 25.3 per cent stated that they were not adequately informed (Perera, 2016, p. 4). This data points out a serious issue regarding the inclusion of affected communities in the decision-making and implementation process, and a challenge in turning Colombo into a safe, inclusive, resilient, and sustainable city as per the sustainable development goal.

This article is organized around three sections. In the first section, attention is on sustainable development as a concept and on sustainable cities, drawing on SDG no.11. In this section the historical evolution of sustainable development as a concept and the specific targets of SDG no.11 are briefly discussed. In the second section, the importance of the concept of inclusion is discussed in relation to sustainable cities and communities, paying special attention to the URP and related slum and shanty relocation processes. Here, the level of inclusion of slum and shanty dwellers in policy formulation and implementation will be examined. The third and final section is dedicated to critically examining how the government managed to exclude slum and shanty dwellers from the decision-making process and how the government justified this exclusion. In this section, modes of exclusion and inclusion are critically analyzed based on ontological and epistemological positions on the matter. Through these sections, the article argues that the Government of Sri Lanka (GoSL) used a positivist stance during the policy formulation process to exclude the slum and shanty dwellers from the decision formulation process and to justify its actions. The article further points out that inclusion of all stakeholders in the decision-making process of the city is essential and discusses how this has become a challenging task in the Sri Lankan context due to various technicalities imposed by the ruling governments from time to time.

\section{Sustainable Development and Sustainable Cities - An Overview}

\section{Sustainable Development}

Sustainable development has become a buzzword in development discourse due to its association with various definitions, meanings, and interpretations (Mensah, 2019). On the one hand, the concept sustainable development contains the two separate concepts of development and sustainability which, when juxtaposed, can result in counterproductive effects (Sharpley, 2000 as cited in Klarin, 2018). On the other hand, as these two concepts 
have been defined separately and independently within different subject fields, the term "sustainable development" has itself resulted in various definitions.

Although the most widely accepted and cited definition of sustainable development was presented in 1987 by The World Commission on Environment and Development in its report Our Common Future, (also known as the Brundtland Report, popularized after the Norwegian Prime Minister Gro Harlem Brundtland who chaired the commission) the idea of sustainable development was presented as early as the early 1800s in Malthus's population theory. Malthus's postulation was that human population growth happens in a geometric progression, while the growth of other natural resources happens in an arithmetic progression (Mensah, 2019). It signaled that at a point in the near future, nature would run out of the essential resources to support the needs of the population. Thus, Malthus pointed out the intrinsic connection between the environment and the human population.

In the late 1980s, The World Commission on Environment and Development (WCED) also known as the Brundtland Commission was established by the United Nations for the purpose of proposing "a global agenda for change" (Strange \& Bayley, 2008). The Brundtland Commission presented the idea of economic prosperity, but with policies focusing on sustaining and expanding the environment base (WCED, 1987). The proposed concept of sustainability in the Brundtland report titled Our Common Future was based on three main pillars; society, the economy, and the environment. The inter-connection of these pillars was pointed out through two main ideas presented by the United Nations General Assembly (UNGA) at the establishment of the Brundtland Commission. First, the UNGA pointed out that the well-being of the environment, of economies, and of people are inextricably linked. Following this, it argued that sustainable development involves co-operation on a global scale (Strange \& Bayley, 2008, p. 24). It was through Agenda 21, published by the United Nations in 1993, that the interconnectedness of three dimensions of sustainable development - society, environment, and the economy - was emphasized. Unfortunately, when implementing Agenda 21, world leaders did not pay adequate attention to this interconnectedness (Department of Economic and Social Affairs of the United Nations Secretariat, 2013).

On its 70th anniversary in 2015, the UNGA declared the adoption of the sustainable development goals, a new set of development goals for the next fifteen years, focusing primarily on achieving sustainability globally. In its resolution The 2030 Agenda for Sustainable Development, the United Nations recognized that eradicating poverty in all forms has become the global challenge which is crucial to attaining sustainable development. Through this resolution it also declared the commitment of world leaders to achieving sustainable development in all three dimensions - economic, social, and the environment in a balanced and integrated manner. Towards this, the UN set up 17 goals and 169 targets (United Nations, 2015).

\section{Sustainable Cities}

The sustainability of urban areas was highlighted under SDG 11 - "[m] ake cities and human settlements inclusive, safe, resilient, and sustainable" - and cities were identified 
as one of the main aspects which required close attention. It was in the Paris Agreement reached at The 21st Conference of the Parties (COP21) of the United Nations Framework Convention on Climate Change (UNFCCC) in early December 2015 that the consistently challenging issues of cities were explicitly mentioned for the first time. The topic emerged again at the New Urban Agenda which was officially launched at the Habitat III global summit in Quito, Ecuador in October 2016 (Simon, 2016, p. 2).

SDG 11 is dedicated to building inclusive, safe, resilient, and sustainable cities and human settlements. It has 10 targets that focus on adequate, safe, and affordable housing and transport systems; inclusive and sustainable urbanization; environmental impact of cities; and integrated policy making towards inclusion (United Nations 2015, p. 24).

Given the increasing acceptance of sustainable cities, many countries around the world believe that building green cities or "eco-cities" to be a good starting point for sustainable development. Sustainable cities combine social development, economic development, environmental management, and urban governance (The Department of Economic and Social Affairs of the United Nations Secretariat, 2013). The integration of all these four dimensions is essential and it can be argued that this whole integration process is based on the concept of inclusion.

\section{Inclusion for a Sustainable City: A Case Study of the Urban Regeneration Project}

Since colonial rule, governments have used various strategies to regulate the spread of slums and shanty dwellers in the city of Colombo, mostly through implementing town planning measures and urban high rises. At the beginning, these measures were preventative and remedial (Panditharatna, 1963), aimed at containing these communities in existing houses by upgrading their living conditions. During these processes, mostly initiated after 1977 through the National Housing Development Authority (NHDA), the State adopted the stance of intervening minimally but supporting the community maximally by providing slum dwellers with necessary guidance and help to upgrade or rebuild their houses, thereby placing the people at the center of house building and house ownership (Abeyasekara et al., 2019). In this way, the State prioritized the needs and interests of citizens by allowing them to create their own lived space. In the last two decades, however, governments have changed their course by addressing the problem through building high rises and relocation.

After 2009, the government's vision was mainly to beautify the city of Colombo (Amarasuriya \& Spencer, 2015; Perera, 2015), and under this vision urban development was carried out under two main projects: (a) the Urban Regeneration Project - initiated under the Urban Development Authority (UDA) of the Government of Sri Lanka (GoSL), and (b) the Metro Colombo Urban Development Project - initiated by the World Bank (Perera, 2020b). The main objective of the Urban Regeneration Project is "to eliminate shanties, slums and other dilapidated housing from the city by relocating dwellers in modern houses" (Urban Development Authority, 2018). Colombo-North and Colombo-East were the areas identified by the UDA as having a higher spread of underserved settlements. The project was planned under three phases with 33 housing projects. The mission of the project was three-fold: 
1. construction of 30,000 low-cost housing units within 3 years and another 40,000 units in the following three years for relocation of households presently located in underserved settlements in the city of Colombo

2. identifying all households located in underserved settlements in order to plan and implement a relocation programme with better living conditions

3. relocation of 70,000 households to the newly built houses through a community development and marketing programme (Urban Development Authority, 2018)

These relocation projects by the UDA were rationalized on the grounds of freeing the land for development, and as a part of it, slum and shanty dwellers who lived on these lands were relocated to sub-standard housing (Amarasuriya \& Spencer, 2015). Although terming these lands as under-utilized to rationalize the relocation and eviction processes was criticized by civil society organizations (Abeyasekera et al., 2019; Perera, 2015), the term "regeneration" used in the project name which provided a space and justification for such action was not critiqued. Commenting on what triggers an urban regeneration process, Amirtahmasebi et al. (2016) point out that in every city there are underused and underutilized lands which weakens the image, livability, and productivity of the city and urban regeneration policies usually target these declining or vacant land parcels. Thus, the term urban regeneration in development discourse means making maximum utilization of the unused, unproductive lands of a city. Nevertheless, some examples on slum renewal policies related to urban regeneration show that they are not entirely successful in terms of sustainability. For instance, in their study of slums in Ethiopia, Teferi \& Newman identified that the policy response for slums in Addis Ababa was based on a negative stance towards the slums whereas modernized high-rise complexes attracted a positive stance $(2017, \mathrm{p}$. 2 ). When assessed in terms of sustainability using the extended metabolism model and the SDGs, they found that although slum clearance and the relocation to high-rises resulted in economic and environmental improvements, they caused the loss of social cohesion amongst slum communities. Based on these findings, Teferi \& Newman suggested the use of more organic approaches based on in situ slum upgrading for an integrated sustainable city (2017, p. 13). Issues similar to the ones in the Addis Ababa slum renewal policy can also be traced in the Urban Regeneration Project in Sri Lanka.

One of the main criticisms against these urban regeneration projects is their arbitrary nature carried out by governments. While from the outset these relocation projects set out to address infrastructural and environmental issues, how much the new houses addressed the actual concerns of relocated communities was questionable. The origin of all these criticisms can be traced back to the issue of inclusion. In one of the first relocation projects in Mews Street, Slave Island, military personnel were involved in the evictions. Their presence was visible not only in the eviction process, but also in grievance management. Some of the affected residents stated that they had to approach senior military officers who oversaw the relocation with their requests and grievances (Perera et al., 2014, p. 11). This militarization of grievance management can be listed as one of the first instances of limiting the space for inclusion, since using the military for civil procedures such as grievance management is a threat to the continuation of fair and open avenues for inclusion 
in a democratic society. In this context, being members of a minority community as well as a community affected by the Urban Regeneration Project, the slum and shanty dwellers of Slave Island were dually affected.

The policy formulation stage of the project was also criticized for providing minimal means for the concerns of relocated communities. For instance, in the case of Mews Street, the residents were not served with appropriate notice, nor were they compensated. The surveys which were not publicly disclosed and the one-time meeting with the target community were termed a "consultation" by the government (Perera, et al., 2014). This meant that the government did not use any effective, appropriate means to allow affected communities to voice their concerns at the policy formulation stage.

This was the same in relation to access to land and land ownership. Although affected families were previously owners of their own lands with deeds, they now had to pay the State roughly $£ 5000$ to obtain the deed of the apartment they were relocated into (Abeyasekera et al., 2019). They were not given compensation (even though they possessed legal deeds) for their lands. The only option presented to them was that of being relocated to an apartment. Furthermore, the families had to pay LKR 100,000 upfront if they wanted to get the key for the apartment (Perera, 2020b).

The new apartment, moreover, was an exchange for a house, not for a family. The authorities took into account neither the size of the family nor whether the house owned previously was a two-floor house or not. Due to this, several families which shared one house faced many difficulties (Abeyasekera et al., 2019). Moreover, the apartment units were selected through a lottery (Abeyasekera et al., 2019), and chances of the whole community being relocated to the same floor in a high-rise was miniscule. The new residents were a mix of people from various parts of the city of Colombo. This disturbed the social relationships and networks they had previously had and led people into isolation in their own apartments (Perera, 2020a).

As mentioned above, the eviction process was involuntary and there was no choice but to accept the government's offer. As there were no proper investigations done on the livelihood strategies of the slum and shanty dwellers prior to their relocation, many of them faced difficulties in continuing income generating activities. According to Perera (2020a), the distances to places of work increased, incurring further expenditure. People who used to run small grocery stalls from home now had to use a part of their living area to conduct their business, limiting the space available for personal use. The inability of the planners to identify these kinds of livelihood needs ran the risk of pushing those relocated into chronic poverty by removing their avenues to sustainable livelihoods.

Compared to the houses the slum and shanty dwellers previously lived in, the new apartments seemed an upgrade to their living conditions. They consisted of two bedrooms, a living room, a kitchen, a bathroom, and a small balcony area occupying 400 square feet, although in later designs this was increased to 500 square feet. Thus, the slum and shanty dwellers were rehoused under a new spatial order, into high rises which consisted of small uniform housing units in what appeared as super modern abodes (Abeyasekera et al., 2019 , p. 218). However, the new occupants were barred from changing or rebuilding the apartments to their own specifications (Perera, 2020b). 
The exclusion of slum and shanty dwellers from consultations in policy formulation and implementation leads to a few important questions. What was the government's justification for excluding this target community which was supposed to be included in the policy making process? Although members of these communities are legal citizens of Sri Lanka, what deprived them from being considered as legal citizens by the UDA? Answers to these questions are not simple and need deeper analysis into the ontological and epistemological stance of the government in decision-making.

\section{Inclusive, Resilient, and Sustainable Cities: A Myth or a Possible Future?}

In cities like Colombo where inhabitants are from various social strata, exclusion from the decision-making process can be complex. While the diversity of inhabitants can lead to a flourishing city, it can also lead to problems of social-spatial polarization and exclusion (Edelenbos \& van Dijk, 2017). As some researchers have pointed out, in urban governance some social strata like slum and shanty dwellers may get excluded in the decision-making process and may have no choice but to follow the policy decisions made by the local or national governing bodies on the use of the urban space. For instance, Mahabir et al. (2016) point out that, as a result of the inability to keep up with the urbanization process due to the lack of resources and corrupt government, there is a fear of establishing property rights for slum dwellers by providing urban services. Governments in less developed countries with a lack of political will to address the issue have failed, thereby, to incorporate slum dwellers as a part of the overall planning process. Moreover, Jones (2017) points out that the growth of informal settlements and slums in developing countries showcases the disconnect between effective spatial management and inclusive planning processes, economic equality, the provision of services and infrastructure, and poverty reduction. Just as these studies suggests, the slum and shanty dwellers in Colombo too have experienced difficulties in being recognized by governments as citizens of the city and included in the decision-making process.

This poses two important and interlinked questions: (1) how does the government exclude some citizens from the decision-making process; and (2) on what basis does it justify the exclusion? According to the concept active citizenship, citizens are not only required to vote at the elections but also participate in the governing process through available ventures. Active citizenship possesses a transformative potential which allows citizens to fight for "transformation of the relationship between the state, market, and civil society in the design and delivery of locally valued products and services" (Mattijssen et. al, 2019, p. 3). Nevertheless, in practice it is evident that governments find ways to surpass this and disenfranchise citizens from the decision-making process. Commenting on the dominance of the positivist-empiricist tradition within the United Kingdom's urban geography, Merrifield (2014) points to how the state has managed to exclude political engagements from the urban matters:

The reason may be obvious in our age of "experts" and "technocrats", in this era some describe as "post-political"; positivism has always hid behind the shield of quantification 
and "objectivity", always tried to rid itself of politics. In that sense, positivism/empiricism is a convenient methodology for technocrats trying to find consensus without conflict. (p. 3)

To elaborate on Merrifield's idea, the discussion should be directed to the positivist stance of the government in decision-making. Current policy decisions are always supported by generalities based on statistical calculations. The decisions are made based on empirical facts which are easily quantifiable and objectified. Thus, it is easy to justify government decisions as they are supported by empirical data. Nevertheless, the danger is that this practice of making decisions based on quantifiable, empirical facts results in excluding the values and subjective realities of citizens. Government decisions end up entirely biased towards a positivist stance. The government sees slums and shanties only as locations, with potential to be developed to its maximum utility, not as perceived space, conceived space, or lived space (Purcell, 2002). Or else, the government sees houses constructed illegally on state land with no proper infrastructure facilities, and not as dwellings which hold closely knit families or communities. When government decisions are backed by empirical data, citizens cannot fight back unless they also use the same to establish their arguments. Citizens cannot fight back on moral grounds because morality is not present in the government's vocabulary. Furthermore, the government can convince citizens based on empirical data and neutralize their bargaining power, thereby reaching for consensus rather than conflict. Therefore, the positivist position of the government's decision-making process can neutralize the political engagement of citizens.

This positivist stance of the government in decision-making is not something new to Sri Lanka. From the British colonial period, policy decisions on managing the urban space, and especially the population growth, were based on empirical data. According to Perera (2005) the collection of census data across the British empire from the 1870s onwards made quantitative data a necessary component in identifying and prescribing necessary solutions to urban related issues in Sri Lanka. For instance, the British Municipal Council Ordinance Number 6 of 1910 stated that it is compulsory for every inhabited room to receive a minimum amount of light and air, further specifying a minimum floor space of 36 square feet and 136 cubic feet of air space per person and restricting 50 persons to an acre (Perera, 2008 , p. 60). This assumed co-relation between light and air, and floor space and air space as a pre-condition for "healthy" and "habitable" conditions for low-income populations is clear evidence that the colonial government was more prone to a positivist position when it came to decision-making and policy formulation. A close look at urban town planning attempts during the British Colonial period can shed more light in this regard. For example, the Slum Survey of 1941 stated that an area about one-eighth of the Colombo city (1132 acres) was covered in slums. This number was used by town planners to design policies under short-term and long-term categories (Panditharatna, 1963, p. 116). This bias towards empirical data started during the British period persists and is still prevalent in planning discourse on Colombo.

Some contemporary evidence in this regard can be found in the relocation processes which took place in Colombo during the past decade. Lands in Colombo, in which slums 
and shanties are situated, are being labeled as "under-utilized prime land", hinting that these lands are currently unavailable for private commercial use. Furthermore, the occupation of these lands by slum and shanty dwellers have been seen by authorities as an impediment to development and growth (Abeyasekera et al., 2019; Perera, 2020a?). As Perera et al., points out the Mahinda Chinthanay $a^{2}$ pledged to build 40,000 apartment units for slum and shanty dwellers and 20,000 luxury and semi-luxury apartments in the formerly underserved areas by 2015 . Concerning this pledge, Perera et al., question whether the government's idea of "40,000 apartment units for the poor" equaling to "20,000 luxury and semi-luxury apartments" can be considered as an equitable way of compensating the affected community, as the slum and shanty dwellers were the original inhabitants in these underserved lands and lost their houses during the urban regeneration project. They also point out that the UDA never became a topic for a debate in the parliament or municipal councils, or even among the public regarding such inequal treatment of the affected communities $(2014$, p. 13). The State was never properly questioned on the morality of its actions. This clearly points to how the cost-benefits involved in these two processes - building 40,000 apartment units for poor and building 20,000 luxury and semi-luxury apartments - managed to override the ethical/ human rights/moral dimensions of the relocation process.

Another aspect to be highlighted is the government's ability and power to assign meanings and define concepts in the policy making process. "Meanings", although considered diverse and plural in a post-modern context, have also become a victim under the government's positivist paradigm. Terms which can carry diverse meanings according to different stakeholders, are now restricted to only one, entirely based on empirical evidence. One such instance is defining the "legality" of the land. Slums and shanties in Colombo are built on state lands, and the majority of the inhabitants do not hold deeds for these lands. This makes the houses built on the land "illegal" and "informal". Gautam Bhan's (2013) analysis of urban planning in New Delhi is useful here. Bhan points out that according to Indian government data, almost $75 \%$ of New Delhi has been living in "unplanned" houses, thus indicate a "failure" in planning. He argues that a different set of questions need to be asked instead: "[h]ow were these categories constructed and defined? What makes one category of housing 'planned' and another 'unplanned'? How do 'planned' and 'unplanned' relate to the 'legal' and the 'formal'? (2013, p. 59). Adding to Bhan, we can also ask: who has the authority to define what is "planned" and "unplanned", and who defines what is "legal" and "formal"? The answer seems obvious - the government. Nevertheless, I intend to analyse this obvious answer much deeper. I argue that the government's definitions of what is being "planned" and "unplanned" and what is "legal" and "formal" is always based on its positivist point of view. For example, in the 2010 Mews Street relocation project, irregular tenure of the inhabitants was used by the UDA to avoid paying compensation. Based on "the fact" that these inhabitants did not have legal deeds for the land, the government was able to easily restrict them from being included into the decision-making process (Perera et al., 2014).

While dwelling on how the government excludes some communities from the decision-making process, it is also important to explore why others are included in building 
a sustainable city. Inclusion is essential because it allows the whole city to be sustainable and resilient. To provide a more elaborate and descriptive answer to this question, the concept of the urban (which includes the city as one of its attributes) should be viewed in ontological terms. In this regard it is worth quoting Merrifield again:

What is being affirmed here is the urban as a single substance whose attributes - the built environment, transport infrastructure, population densities, topographical features, social mixes, political governance - are all the formal expressions of what pervades it ontologically. We might even say that the "city" is an attribute of the urban. These attributes are how the urban looks and how it can be seen and known. The urban isn't out there, necessarily observable and measurable but is immanent in our lives, an ontology not an epistemology, not a transitive attribute of our society but the immanent substance of our society. (2014, p. 5)

Viewing the urban, and in this case the city, through an ontological lens might seem quite absurd for government bureaucrats and technocrats. However, it is only as an ontology that we may be able to perceive the nuances that exist in the concept or urban and/ or city. Considering the city to be a mere collection of built environments or infrastructure excludes the essence of the city. A city becomes a living organism only when it relates to its inhabitants. A city is not just a geographical location; it is also a lived space and a shared space of inhabitants. It is not something which can be objectively observed or measured entirely. Within its built environment and infrastructure, inhabitants create their space. A city gets its life and characteristics from its inhabitants and their behavior. Thus, making decisions about managing the space of the city, whether this be relocating certain communities or zoning the city based on a logical plan, without consulting or including its inhabitant might result in failure as the planning would not have captured the driving essence of the city - its inhabitants. Therefore, a city should be seen as a part of its society, which lives, changes, and grows with its inhabitants.

Thus, this discussion on viewing the city from an ontological perspective leads to one last question: how can the inclusion of formerly marginalized and excluded communities into the decision-making process of urban development assist in making the city sustainable and resilient? On the one hand, to achieve sustainability, all the three pillars of society, economy, and the environment should be equally protected and integrated into the governance process. This means integrating society as a whole, the economy as a whole, and the environment as a whole when formulating state policies. If some communities are excluded from a particular society, it cannot be considered a whole society. The same applies if some economic practices are excluded from an understanding of a particular economy. Even if the voices of certain communities and economic practices are excluded in the decision-making process, it does not mean that they are absent in the real life. Excluding the concerns and demands of vulnerable communities in the decision-making process can result in incompatible policy decisions to the actual problem. This can directly affect the sustainability of the city. 
On the other hand, for the city to be resilient it should possess the ability to absorb, recover from, and prepare for future shocks - economic, environmental, social, and institutional (Organization for Economic Co-operation and Development, n.d.). This ability cannot be developed unless the government is aware of all the concerns and issues of the society, economy, and environment of the city. Exclusion of any type of demand or concern of a particular section of the society, economy, or environment would provide an incomplete picture of the actual situation and would lead to the city reacting poorly to unforeseeable shocks. The inability of some communities to absorb, recover from, and prepare for future shocks would affect the entire fabric of the city.

All these concerns highlight the necessity for a comprehensive approach to address the issue of inclusion in urban sustainability in the city of Colombo. The four-stage approach in the Urban Sustainability Framework (USF) provided by the World Bank can be used as a possible road map to design appropriate policy measures in Sri Lanka. The flexible nature of this approach is useful in addressing both short-term and long-term proposals for development (World Bank, 2018, p. 12)

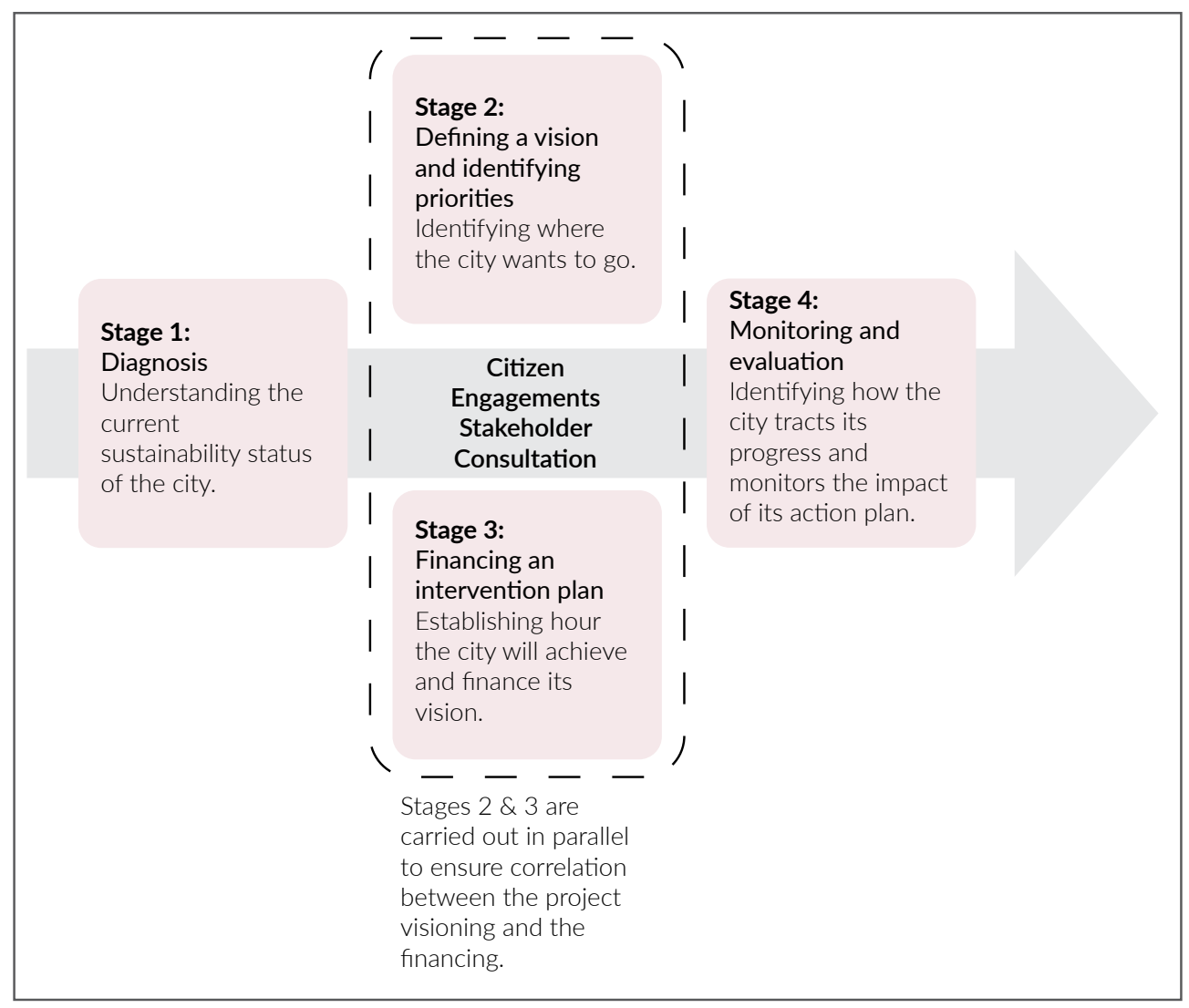

Figure 1

The Four Stages of the Urban Sustainability Framework Process

Note: Extracted from The World Bank. (2018). Urban Sustainability Framework (USF). 
The appropriateness of this framework for the relocation process in Colombo lies in the importance it assigns to "citizen participation and stakeholder consultation". This happens as a cross-cutting process through each stage, would ensure transparency, and allow citizens to evaluate the particular actions undertaken, by making the results public (World Bank, 2018, p. 52).

While this framework can be beneficial in inventing a smooth process for relocation projects in Colombo with a cross-cutting process of inclusion, we should also take into account the contextual challenges which might occur. It is important to identify the challenge of initiating effective means of inclusion at every step of the USF process within the Sri Lankan context. For instance, in the first step of "diagnosis", the World Bank showcases an example from Boston, U.S.A., where the city authorities have been using an online tool called CityScore. Through CityScore, data related to 21 different metrics have been collected from the city of Boston, and both residents and the authorities have been using them to improve their performance results (World Bank, 2018, p. 16). Such an online tool can be modified in accordance with other relocation projects, but in the Sri Lankan context, using such a tool might be problematic due to a number of causes. While city dwellers might face issues such as the lack of information technology literacy and availability of electronic devices with compatibility to a particular online tool, city officials might face difficulties in popularizing the online tool among city dwellers as a reliable means of providing information and managing human and financial resources. Adopting sophisticated online tools under a traditional bureaucratic decision-making and administrative system would also be a challenge.

Nevertheless, even this USF process puts us back at square one when it comes to the positivist outlook of the government. While online tools or other similar means of inclusion open up a pathway for citizens to share their concerns, it would not make much of a difference if the nature of the tool allows only certain types of data to be collected. For example, through such tools it is possible to collect quantitative data and, in some instances, assess public perceptions, but they would not be suitable for capturing the nuances and delicate human problems associated with emotions and social relationships in the city. Thus, the means of inclusion should be broadened even more to also capture the sensitive qualitative data. Whether this is possible or not is something to be investigated in another setting.

Thus, it is evident that developing sustainability and the resilience of a city is an integrated process. It should not be advocated individually and in an abstract fashion. Accounting for the interlinkages of society, the economy, and the environment is compulsory for appropriate and fair policy decisions. Discriminating against communities based on their class, caste, or economic status would not benefit the city in the long run, as the city is a living, integrated organism. Therefore, it can be argued that to make a sustainable city, the inclusion of all of its inhabitants is essential. This would allow governing bodies to make appropriate and successful policy decisions which would increase the possibility of creating sustainable and resilient cities in the future. In the meantime, it should also be noted that behind promoting inclusion, a complete makeover of traditional bureaucratic 
systems is also necessary. While the decision-making process should open avenues for new means of inclusion, the administrative infrastructure which supports such change should also be renewed.

\section{Conclusion}

Sustainable cities in the 21 st Century have grown beyond the concept mentioned in the sustainable development goals. Now it is not just a development goal followed globally, but a far more complex phenomenon which deals with power struggles and power relations. Due to this fact, building a sustainable city has become a political project as well. Although internationally accepted guidelines suggest promoting inclusion in the decisionmaking process, various example show that in practice, there is more exclusion than inclusion in urban governance and decision-making. Excluding vulnerable groups such as slum and shanty dwellers when making decisions has become a common scenario and such exclusions are being justified by the governments hiding behind objective-empirical data. The widespread acceptance of the positivist tradition has caught even the State in its grip. Bureaucrats and technocrats with a positivist outlook have been using statistical generalizations to support government policy decisions for a long time. This tendency to view social issues which deal with human perception and emotions from a positivist point of view has resulted in incompatible policy solutions for particular social issues. This has created a mismatch between the problem and the solution, thereby creating obstacles in the path to achieving sustainability.

The Sri Lankan government's policies under the Urban Regeneration Project, and the slum and shanty relocation processes are prime examples of the above. Disenfranchising the citizen from the decision-making process based on "objective" statistical and legal claims has been one of the prime reasons for the failure of the slum and shanty relocation projects. Although these projects claim to upgrade the living conditions of slum and shanty dwellers by relocating them into modern housing in the government-built high-rises (from the government's point of view), excluding them from the decision-making process at every stage (planning, building, evicting, relocating etc..) has laid the cornerstone for an unsustainable city in the long run. The sole focus on the physical improvement of the living conditions, and zero focus on livelihood strategies, personal space, communal ties, and personal desires of the slum and shanty dwellers has produced an uneven development and a low ability to be resilient.

1. The term "houses" is used in this article to refer to apartments in the high-rises which were built by Urban Development Authority (UDA) under the Urban Regeneration Project. Under the vision of the Urban Regeneration Project, the official terminology used by the Urban Development Authority to refer to the apartments in the high-rises' is "modern houses". Please refer to https://www.uda.gov.lk/urban-regeneration-programme.html

2. Mahinda Chinthana - A Vision for Future or publicly known as Mahinda Chinthanaya is the presidential election manifesto of the former president Mahinda Rajapaksa, published aiming at the 2010 presidential election. 


\section{References}

Abeyasekera, A., Maqsood, A., Perera, I., Sajjad, F., \& Spencer, J. (2019). Discipline in Sri Lanka, punish in Pakistan: Neoliberalism, governance, and housing compared. Journal of British Academy, 7(s2), 215-244. https://doi.org/10.5871/jba/007s2.215

Amarasuriya, H., \& Spencer, J. (2015). "With that, discipline will also come to them": The politics of the urban poor in postwar Colombo. Current Anthropology, 56(S11), S66-S75. https://doi. org/10.1086/681926

Amirtahmasebi, R., Orloff, M., Wahba, S., \& Altman, A. (2016). Regenerating urban land: A practitioner's guide to leveraging private investment. The World Bank.

Bhan, G. (2013). Planned illegalities - housing and the 'failure' of planning in Delhi: 1947-2010. Economic and Political Weekly, XLVIII(24), 58-70.

Department of Economic and Social Affairs of the United Nations Secretariat. (2013). World economic and social survey 2013: Sustainable development challenges. United Nations.

Edelenbos, J., \& van Dijk, M. P. (2017). Introduction: From urban management to urban governance. In Urban Governance in the Realm of Complexity (pp. 1-22). https://doi. org/10.3362/9781780449685.001

Eremia, M., Toma, L., \& Sanduleac, M. (2017). The smart city concept in the 21 st Century. Procedia Engineering, 181, 12-19. https://doi.org/10.1016/j.proeng.2017.02.357

Jones, P. (2017). Formalizing the informal: Understanding the position of informal settlements and slums in sustainable urbanization policies and strategies in Bandung, Indonesia. Sustainability (Switzerland), 9(8). https://doi.org/10.3390/su9081436

Klarin, T. (2018). The concept of sustainable development: From its beginning to the contemporary issues. Zagred International Review of Economics \& Business, 21(1), 67-94. https://doi. org/10.2478/zireb-2018-0005

Mahabir, R., Crooks, A., Croitoru, A., \& Agouris, P. (2016). The study of slums as social and physical constructs: Challenges and emerging research opportunities. Regional Studies, Regional Science, 3(1), 399-419. https://doi.org/10.1080/21681376.2016.1229130

Mattijssen, T. J. M., Buijs, A. A. E., Elands, B. H. M., Arts, B. J. M., van Dam, R. I., \& Donders, L. M. (2019). The transformative potential of active citizenship: Understanding changes in local governance practices. Sustainability, 11(20), 5781, 1-16. https://doi.org/10.3390/su11205781

Maunier, R. (1910). The definition of the city. American Journal of Sociology, 15(4), 536-548. https://www.jstor.org/stable/2762461

Mensah, J. (2019). Sustainable development: Meaning history, principles, pillars and implications for human action: Literature review. Cogent Social Sciences, 5(1). https://doi.org/10.1080/2331 1886.2019.1653531

Merrifield, A. (2014). The new urban question. Pluto Press. 
Organization for Economic Co-operation and Development. (n.d.). Resilient cities. Retrieved from https://www.oecd.org/cfe/regionaldevelopment/resilient-cities.htm\#: :text=Resilient $\% 20$ cities $\% 20$ are $\% 20$ cities $\% 20$ that,cities $\% 20$ can $\% 20$ increase $\% 20$ their $\% 20$ re\%E2\%80\%9Cjavascript:alert(document.\%20lastModified)\%E2\%80\%9Dsilience.

Panditharatna, B. L. (1963). A critical review of plans for the development of Colombo City and some trends in planning. Ceylon Historical and Social Studies Publication Board, 6(2), 111-123.

Perera, I. (2015). Forced evictions in Colombo: High-rise living. Center for Policy Alternatives.

Perera, I. (2016). Living it down: Life after relocation in Colombo's high rises - a survey of households relocated by the Urban Regenration Project. Center for Policy Alternatives.

Perera, I. (2020a). "We can't feel the earth beneath our feet anymore": Dispossession and high-rise living in Colombo. Polity, 8(1\&2), 51-56.

Perera, I. (2020b). The Urban Regeneration Project. Bank Information Center.

Perera, I., Ganeshathasan, L., Samaraarachchi, S., \& Ruwanpathirana, T. (2014). Forced evictions in Colombo - the ugly price of beautification. Center for Policy Alternatives.

Perera, N. (2005). Importing urban problems: The impact of the introduction of the housing ordinance in Colombo. Arab World Geographers, 7(1-2), 61-76. https://doi.org/10.5555/arwg.8.1$2.0 \mathrm{q} 47414 \mathrm{r} 11 \mathrm{k} 1746$

Perera, N. (2008). The planners' city: The construction of a town planning perception of Colombo. Environment and Planning, 40, 57-73. https://doi.org/10.1068\%2Fa3987

Purcell, M. (2002). Excavating Lefebvre : The right to the city and its urban politics of the inhabitant. GeoJournal, 58(2/3, Social Tranformation, Citizenship, and the Right to the City), 99-108. https://doi.org/10.1023/B:GEJO.0000010829.62237.8f

Simon, D. (Ed.). (2016). Rethinking sustainable cities - accessible, green and fair. Policy Press.

Strange, T., \& Bayley, A. (2008). Sustainable development - linking economy, society, environment. The Organisation for Economic Co-operation and Development.

Teferi, Z. A., \& Newman, P. (2017). Slum regeneration and sustainability: Applying the extended metabolism model and the SDGs. Sustainability, 9(12), 2273, 1-16. https://doi.org/10.3390/ su9122273

The United Nations. (n.d). The 17 goals. https://sdgs.un.org/goals

The United Nations. (2015). Transforming our world: The 2030 agenda for sustainable development $(\mathrm{A} / \mathrm{RES} / 70 / 1)$.

UNHabitat. (2020). What is a city?

https://unhabitat.org/sites/default/files/2020/06/city_definition_what_is_a_city.pdf

Urban Development Authority. (2018). Urban Regeneration Programme. https://www.uda.gov.lk/ urban-regeneration-programme.html 
Williams, O. P. (1975). The politics of urban space. Publius, 5(1), 15-26. https://doi. org/10.2307/3329380

The World Bank. (2018). Urban sustainability framework (USF).

World Commission on Environment and Development. (1987). Report of the world Commission on Environment and Development: Our common future. https://sustainabledevelopment.un.org/ content/documents/5987our-common-future.pdf

Wu, J. (2010). Urban sustainability: An inevitable goal of landscape research. Landscape Ecol, 25, 1-4. DOI 10.1007/s10980-009-9444-7

Zhang, X. Q. (2015). The trends, promises and challenges of urbanization. Habitat International, 1-25. https://doi.org/10.1016/j.habitatint.2015.11.018 